\title{
AlB Dissertation Awards: The Early Years (1968-1985)
}

\author{
John D. Daniels, University of Miami (Emeritus), USA \\ José R. de la Torre, Florida International University (Emeritus), USA
}

Last year, the late Alan Rugman (2013) published a piece in AIB Insights in which he recounted the recent history of the AIB Dissertation Award. In it, Alan describes the decision by the Executive Board of the AIB in April of 1986 as one that "formalized" the awards through the acceptance of a report by an ad-hoc committee established for that purpose and which had proposed a set of guidelines for future awards. Shortly thereafter, beginning in 1987, the awards were named after Richard N. Farmer, the legendary professor of international business at Indiana University, former AIB President, one of the earliest pioneers of our field and mentor to a whole generation of IB doctoral students who lobbied for naming the award in his honor. A quarter century later, the AIB Board renamed the dissertation award in honor of Peter J. Buckley and Mark Casson, two outstanding scholars responsible for the early development of internalization theory, one of the foundational approaches to the study of multinational enterprises.

Rugman's article provides a rich description of the development of these awards over the past 28 years. He traces their evolution in terms of two important trends: the growth of scholarly work on institutional aspects of international business and the greater importance of work carried out outside the United States in recent years.

Facing a scarcity of data, the article provides no coverage of the early years of the award, that is, beginning with its debut in 1968. There is also an implication that previous awards were somehow ad-hoc in nature. In any event, little information was provided that would allow us to complete the picture on the evolution of doctoral research in our field. Consequently, we have taken on the task of examining these earlier awards, their subjects and recipients, and we have attempted to shed some light on the development of our IB research in these formative years of our Academy.

\section{Methodology}

As we sought information on early award years, we ran into a number of obstacles. We relied on John Fayerweather's history of the AIB's first 25 years of existence (1986) to find the names of early winners. ${ }^{1}$ Since his listing did not include dissertation titles, we searched through the University Microfilms in Ann Arbor, Michigan - both online and in bound volumes - and supplemented this information with Google Scholar searches of, and emails with, past winners. ${ }^{2}$ All early winners and titles are listed on Table 1, and we are confident that this information is both complete and correct.

We consulted incomplete AIB Board meeting minutes (sometimes undated) to determine procedural changes and policies, and we contacted three former AIB presidents (Jack Behrman, Robert Stobaugh and Art Stonehill) and a former Executive Secretary (James Goodnow), all of whom had been heavily involved in the organization's early years, to ascertain their recollections. Unfortunately, so many years have transpired that many details were lost. Since we were both involved with the AIB almost from the onset of the dissertation awards, we were able to recall certain things. However, we readily admit that there are gaps in this part of our paper. Perhaps the most frustrating inquiry came as we sought to find out where past winners are today. Many of them "fell off the map" many years ago. We have indicated on Table 1 the "last known" location for all winners, but some of this information is dated and may be incorrect. We also found no record of other finalists, thus perforce we had to depend only on winning dissertations to draw conclusions such as on topics chosen for study. (On reading this, if you find any errors or can fill in any gaps, let us know so that we can make corrections for the AIB archives.)

\section{The Rationale and Early Structure of the Disserta- tion Award}

The earliest reference we could find to the organization of any dissertation awards is in John Fayerweather's AIB history. He describes the Board's intention as follows:

[In order] to foster doctoral work, an annual award for a superior dissertation was proposed. The concept was a simple one, which received ready support, and the first award was made in 1968 to J.W.C. Tomlinson...

At the outset there were few candidates and the process was handled rather informally. However, formal procedures were quickly needed, and a set of rules was set forth in 1973. Three senior persons in the field of international business were designated [presumably by the Board] as the Selection Committee. Entries were made by submission of a ten-page summary of the dissertation. From these papers four finalists were selected. Their full dissertations were read by the committee in making the final choice for first and second place awards. With various modifica- 
Table 1: Dissertation Award Winners 1968-1985

\begin{tabular}{|c|c|c|c|c|c|}
\hline Year & Winner & $\begin{array}{l}\text { Granting } \\
\text { Institution }\end{array}$ & Dissertation Title & $\begin{array}{l}\text { AIB } \\
\text { Member? }\end{array}$ & Last Known Position \\
\hline 1968 & $\begin{array}{l}\text { James W.C. } \\
\text { Tomlinson }\end{array}$ & MIT & A Model of the Joint Venture Decision Process in International Business & no & U. of British Columbia \\
\hline 1969 & John D. Daniels & U. of Michigan & $\begin{array}{l}\text { Recent Foreign Direct Manufacturing Investment in the United States: An } \\
\text { Interview Study of the Decision Process }\end{array}$ & yes & U. of Miami (emeritus) \\
\hline 1970 & José R. de la Torre & Harvard U. & $\begin{array}{l}\text { Exports of Manufactured Goods from Developing Countries: Marketing } \\
\text { Factors and the Role of Foreign Enterprises }\end{array}$ & yes & $\begin{array}{l}\text { Florida International U. } \\
\text { (emeritus) }\end{array}$ \\
\hline 1971 & Jeffrey S. Arpan & Indiana U. & International Intracorporate Pricing: Non-American Systems and Views & deceased & U. of South Carolina \\
\hline 1972 & James J. Ward & $\begin{array}{l}\text { George } \\
\text { Washington U. }\end{array}$ & Product and Promotion Adaptation by European Firms in the U.S. & no & NA \\
\hline 1973 & Lee H. Radebaugh & Indiana U. & $\begin{array}{l}\text { Accounting for Price Level and Exchange Rate Changes of United States } \\
\text { Firms with Manufacturing Subsidiaries in Brazil }\end{array}$ & yes & Brigham Young U. (emeritus) \\
\hline 1973 & Claude L. Simpson & Georgia State U. & $\begin{array}{l}\text { The Export Decision: An Interview Study of the Decision Process in } \\
\text { Tennessee Manufacturing Firms }\end{array}$ & no & Northeast Louisiana U. \\
\hline 1973 & Arnold K. Weinstein & Columbia U. & $\begin{array}{l}\text { The Overseas Investment Decisions of U.S. Multinational Advertising } \\
\text { Agencies }\end{array}$ & no & NA \\
\hline 1974 & Edward B. Flowers & Georgia State U. & Oligopolistic Reaction in European Investment in the United States & no & St. John's U. \\
\hline 1975 & Ah B. Sim & UCLA & $\begin{array}{l}\text { Decentralization and Performance: A Comparative Study of Malaysian } \\
\text { Subsidiaries of Different National Origins }\end{array}$ & yes & U. of Wollongong \\
\hline 1976 & Gerard B. J. Bomers & U. of Washington & $\begin{array}{l}\text { Multinational Corporations and Industrial Relations: A Comparative Study } \\
\text { of West Germany and the Netherlands }\end{array}$ & no & $\begin{array}{l}\text { Netherlands School of } \\
\text { Business }\end{array}$ \\
\hline 1977 & Robert D. Tamilia & Ohio State U. & $\begin{array}{l}\text { A Cross-Cultural Analysis of Selected Source Effects on Information } \\
\text { Processing in an Advertising Context: An Empirical Study of French and } \\
\text { English Canadian Consumers }\end{array}$ & no & U. of Quebec at Montreal \\
\hline 1978 & Michael A. Amsalem & Harvard U. & $\begin{array}{l}\text { Technology Choice in Developing Countries: The Impact of Differences in } \\
\text { Factor Costs }\end{array}$ & no & $\begin{array}{l}\text { Midsummer Capital LLC (New } \\
\text { York), CEO }\end{array}$ \\
\hline 1978 & $\begin{array}{l}\text { Ruediger Neumann- } \\
\text { Etienne }\end{array}$ & U. of Michigan & Exchange Risk in Foreign Operations of Multinational Corporations & no & $\begin{array}{l}\text { Intertec Group (Palo Alto) } \\
\text { Managing Director }\end{array}$ \\
\hline 1979 & Sarkis J. Khoury & $\begin{array}{l}\text { U. of } \\
\text { Pennsylvania }\end{array}$ & $\begin{array}{l}\text { International Banking, Its Scope and Raison d'Être: A Special Look at } \\
\text { Foreign Banks in the United States }\end{array}$ & no & $\begin{array}{l}\text { U. of California, Riverside } \\
\text { (retired) }\end{array}$ \\
\hline 1980 & William H. Davidson & Harvard U. & $\begin{array}{l}\text { Corporate Experience Factors in International Investment and Licensing } \\
\text { Activity }\end{array}$ & no & $\begin{array}{l}\text { MESA Development (Los } \\
\text { Angeles), CEO }\end{array}$ \\
\hline 1981 & Viem Kwok & $\begin{array}{l}\text { U. of California, } \\
\text { Berkeley }\end{array}$ & An Analytical Derivation of Optimal Joint-Venture Agreements & no & $\begin{array}{l}\text { CITIC Resources Hold. Ltd. } \\
\text { (Hong Kong) Chairman }\end{array}$ \\
\hline 1982 & Erdogan Bilik & Ohio State U. & $\begin{array}{l}\text { Forecasting Accuracy of Forward Exchange Rates and the Efficiency of } \\
\text { the Market for Foreign Exchange: An Inquiry into the Performance of the } \\
\text { Foreign-Exchange Forecasting Industry }\end{array}$ & no & $\begin{array}{l}\text { Financial Services Professiona } \\
\text { (Los Angeles) }\end{array}$ \\
\hline 1982 & Douglas W. Nigh & UCLA & $\begin{array}{l}\text { Political Events as Environmental Determinants of United States } \\
\text { Manufacturing Direct Foreign Investment }\end{array}$ & deceased & U. of South Carolina \\
\hline 1983 & Kate Gillespie & U. of London & $\begin{array}{l}\text { Foreign Investment and the Tripartite Relationship: Government, Foreign } \\
\text { Investors, and Local Investors During Egypt's Economic Opening }\end{array}$ & yes & U. of Texas, Austin \\
\hline 1984 & John J. Dugan, Jr. & Temple U. & $\begin{array}{l}\text { The Relationship between Culture and Managers'Behavioral Decisions: } \\
\text { A Two-Country Study of the Preference Formation and Choice Processes } \\
\text { (Comparative, Motivation, Expectancy; United States, India) }\end{array}$ & no & Aviation Consulting Inc. \\
\hline 1985 & L. Jeremy Clegg & U. of Reading & $\begin{array}{l}\text { The Determinants of International Production: A Comparative Study of Five } \\
\text { Developed Countries }\end{array}$ & yes & U. of Leeds \\
\hline 1985 & Leo Sleuwaegen & $\begin{array}{l}\text { Catholic U. of } \\
\text { Leuven }\end{array}$ & $\begin{array}{l}\text { Location and Investment Decisions by Multinational Enterprises in } \\
\text { Belgium and Europe }\end{array}$ & yes & KU Leuven \\
\hline
\end{tabular}


tions, this system has continued since then with general success. (pp. 25-26)

At first, the winner and top finalist of the dissertation competition were announced publicly in the program and were asked to present their work at the Annual Meeting of the AIB. For a few years, beginning in 1970, the second place finalist was asked instead to serve as discussant to the winner's presentation of his/her work. Needless to say, this created an awkward situation whereby the second place finisher was tempted to use the occasion to prove to the audience why the winning selection was not worthy of the award. By the mid-70s a more collegial approach was chosen, whereby a number of finalists (initially three, later four) were asked to present at a special session of the Annual Meeting, but no one knew beforehand who had won. It was not until the conclusion of the session that the winning dissertation was announced by the Chair of the committee, who would normally preside over the session.

The structure of the Selection Committee also evolved over time. The initial "three wise men" (all were men in those early days) approach identified by Fayerweather gave way to a process by which a committee chair would be appointed who, in turn, would select the other members.

Although the records of AIB Executive Board meetings are spotty, they yielded some relevant information on the process by which more formal procedures were adopted. For example:

- An item in the minutes of the October 27, 1973, meeting of the Executive Board (p. 4) indicates a decision taken to "award framed certificates to all winners." Prior to this, no certificate or plaque was awarded, and there certainly was no cash prize associated with the award. Both of the authors received their respective plaques only years later.

- The Executive Board minutes of a meeting held in New York City on December 26, 1973 (presumably just before the start of the annual meeting that year), notes that, "There was a discussion of the system of judging dissertations. Bob Stobaugh [then Vice President of the AIB] agreed to draft a set of instructions for future contests, for consideration by the Board."

At the next Board meeting on April 20, 1974, the following guidelines were indeed adopted:

\section{A. Submission}

Although traditionally faculty members nominated outstanding dissertations from their respective schools, students may submit dissertations themselves. The only regulation that is adhered to rather strictly is that the dissertation be from international business rather from economics and other fields. ${ }^{3}$

\section{B. Selection to avoid partiality}

It is recommended that the review of the dissertations be by senior people in the field of international business ... [This] will add to the prestige of the award ...
It is recommended that a heterogeneous group of readers be used so as to avoid possible functional bias.

\section{Number of winners}

... The committee reviewing the dissertations should decide the number of awards and whether any ranking should be made. However, normally one paper (sic) will be selected as a winner and 2 as runners up."

\section{Presentation of papers}

The winner or winners of the dissertation awards should be present at the annual meeting to present a paper based on his or her dissertation. The paper will conform to the guidelines for submission of other professional papers of the AIB normal paper presentations... As with other papers submitted to the AIB the Journal of International Business Studies will have first right to publish an article based on the winning dissertation. This article will be subject to the normal editorial process which is used for all papers submitted to the Journal.

The records appear to indicate that Prakash Sethi was appointed chair of the committee in 1977, and Steve Kobrin in 1978 (no other names were found in the available minutes). Later on, probably starting in 1979, Jeffrey Arpan, himself a winner of the award in 1971, was made a permanent chair of the selection committee, a position he held until 1986. During this seven-year period, three other members rotated in and out on the committee on a three-year schedule. Eventually, beginning with 1987, the current structure by which the longest serving member of the committee became its chair and then rotated out the following year was adopted. ${ }^{4}$ See Table 2 for a list of all committee chairs whose names are available.

\section{Winner Profiles}

Before the initiation of the Farmer Dissertation Award, there were 23 dissertation winners from 16 institutions over a 17-year period. The difference between the number of years and winners was due to ties in four different years (1973, 1978, 1982 and 1985). The first 19 winners were all males and all from universities within the United States. This pattern was broken in 1983 when Kate Gillespie became both the first female and first winner from a university outside the United States (University of London). In 1985, two other winners from non-US universities (L.J. Clegg from the University of Reading and Leo Sleuwaegen from the Catholic University of Leuven) were added to the list. Thus, in these early years, women accounted for only 4 percent and non-US universities for 13 percent of winners. In contrast, in the subsequent 28 years the percentage of female and non-US university winners increased to 39 percent each, which undoubtedly reflects the impacts of greater female participation in higher education programs and in the globalization of IB research and AIB membership. 
Table 2: AIB Dissertation Award Committee Chairs

1968-69 Unknown

1970 Vern Terpstra, U. of Michigan

1971-76 Unknown

1977 Prakash Sethi, City U. of New York

1978 Steve Kobrin, New York U.

1979-86 Jeffrey Arpan, U. of South Carolina

1987 José de la Torre, UCLA

1988 Yves Doz, INSEAD

1989 Steve Kobrin, The Wharton School

1990 Susan Douglas, New York U.

1991 Don Lessard, MIT

1992 Robert Grosse, Thunderbird

1993 Yair Aharoni, Duke U.

1994 Robert Green, U of Texas, Austin

1995 Alan Rugman, U. of Toronto

1996 Ravi Ramamurti, Northeastern U.

1997 Lee Radebaugh, Brigham Young U.

1998 John Ryans, Kent State U.

1999 Kendall Roth, U of South Carolina

2000 Jean-Francois Hennart, Tilburg U.

2001 Raj Aggarwal, Kent State U.

2002 Nakiye Boyacigiller, San José State U.

2003 Kiyohiko Ito, U. of Hawaii at Manoa

2004 Bernard L. Simonin, Tufts U.

2005 Elearnor Westney, MIT

2006 Cristina Gibson, U of Western Australia

2007 Elizabeth Rose, U. of Otago, New Zealand

2008 Gary Knight, Florida State U.

2009 Mary Zellmer-Bruhn, U of Minnesota

2010 Jennifer Spencer, George Washington U.

2011 Simon Bell, U. of Melbourne

2012 Mike Peng, $U$ of Texas at Dallas

2013 Alan Rugman, U. of Reading

\section{Dissertation Topics}

Among the first 23 awards, the topics included work that ran the gamut of functional areas - accounting, finance, human resources, management, marketing and production. They included both comparative and cross-national management studies involving firms from both developed and developing countries. They covered most modes of international business, i.e., trade in both products and services, licensing, joint ventures and wholly-owned foreign operations. Given this diversity, categorizing major emphases is difficult, but we nevertheless identify at least four characteristics of this early work:

1. Foreign operations in the United States. Despite most dissertations emanating from the United States, there was considerable interest in non-US companies. Putting this in context, in the immediate post-World War II years nearly all outward FDI emanated from the United States, and it is fairly safe to say that nearly all studies during that period, both macro and micro, emphasized these outward movements. However, by 1968, the first year of the AIB Dissertation Award, this situation was changing and was quickly reflected in IB research with such topics as FDI into the US (Daniels, 1969), product and promotion adaptation by European companies in the United States (Ward, 1972), oligopolistic reaction by European investors in the United States (Flowers, 1974) and foreign banks in the United States (Khoury, 1979).

2. Foreign exchange. Again, this emphasis is best put into context. From 1944-1971, currency rates were fixed to the US dollar, which, in turn, was fixed to a price of $\$ 35$ per ounce of gold. During this period, foreign exchange risk was a one-way street as currencies sometimes devalued, but seldom revalued relative to the US dollar. Between 1971 and 1973 this situation changed with the suspension of convertibility of the US dollar into gold and the emergence of the managed float system. Thus, foreign exchange risk became an important issue. Three early dissertation winners (Radebaugh, 1973; Neumann-Etienne, 1978; Bilik, 1982) seized on these changes respectively by studying the effects on accounting for value changes, ways for management to cope with such changes and the performance of the foreign exchange forecasting industry.

3. Cross-cultural operational differences. Much of the early work in international business dealt with cross-cultural differences that prompted questions on the universal applicability of management. ${ }^{5}$ Concomitantly, dissertation winners studied variances in how nationalities dealt with transfer pricing (Arpan, 1971), how different MNE nationalities managed differently within Malaysia (Sim, 1975), how French and English speakers within Canada contrasted in their responses to advertising (Tamilia, 1977) and how Indian and US managers' behavioral and decision processes differed (Dugan, 1984).

4. Dependence on interviews. While methodology differed among these studies, we could not help but notice when examining their abstracts that a seemingly high proportion of dissertations depended on collecting primary data through company interviews. If correct, there are probably two primary reasons. First, other than the Harvard Business School's multinational enterprise project (founded in the early 1960s) that developed information on the international activities of a large number of US companies, there was scant available data at the firm level from databanks. Second, it is probably safe to say that in the 1968-1985 period there were far fewer academic requests for access to companies and their data (with the implied time necessary for their managers to supply information) than is currently the case. Thus, such primary data collection has become progressively more difficult as companies have rationed their availability.

\section{The Winners Now}

In trying to locate early winners, three things surprised us. First, we expected to find most of them through the AIB membership list, but as of May 25, 2014, only seven were still members. Excluding two former 
winners known to be deceased, only one-third of past winners remained in the AIB. Second, given the scholarship required for a winning dissertation, we expected that many more than four (17 percent) to have become AIB Fellows in subsequent years. These four took an average of a little over 20 years to be elected to the Fellows after receiving their awards. In contrast, three winners since 1986 are Fellows, and they took an average of 15 years since receiving their awards to gain this status. Third, we have all heard the expression, "Those who can, do; those who can't, teach." But apparently six of the past winners "can do, and don't teach." From all indications, they are all highly successful executives, holding such titles as CEO, Chairman and Managing Director of their respective companies. None of these are currently AIB members.

\section{Recommendations for the Future}

Given the importance we attribute to winning the annual dissertation competition, and the impact that such exemplar work can have on future scholars in our field, we believe that the AIB should make a stronger effort to preserve this information and make it available to the membership. For example, we feel that the AIB Secretariat should maintain files (physical or electronic) of dissertations for all past winners and, at a minimum, maintain abstracts for other competitors' submissions. To go even further, archives might include all IB-related dissertation abstracts, and these should be searchable by our members. Given Web-based information sources, this should be doable. ${ }^{6}$

Our Academy should make a strong effort toward retention of past winners. Some alternative practices may include invitations for them to be on special panels (e.g., those now in the private sector may have many useful messages to pass on), getting them involved in reviewing papers and developing special events where past winners and finalists can interact.

In summary, we feel that the collective wisdom and experience of past winners of the dissertation awards is a precious asset that the AIB should try to preserve for future generations of scholars.

\section{References}

Fayerweather, J. 1986. A history of the Academy of International Business from infancy to maturity: The first 25 years. Essays in International Business, No. 6 (November). Columbia, SC: Center for International Business Studies, University of South Carolina.

Farmer, R. N., \& Richman, B. M 1965. Comparative management and economic progress. Homewood, IL: Richard D. Irwin.

Koontz, H. 1969. A model for determining the universality of management. Academy of Management Journal, 12(4): 415-429.

Negandhi, A. R., \& Estafan, B. D. 1965. A research model to determine the applicability of American know-how in different cultures and/or environments. Academy of Management Journal, 8(4): 309-318.
Nehrt, L. C., Truitt, J. F., \&Wright, R. W. 1970. International business research: Past, present and future. Bloomington, IN: Indiana University Bureau of Business Research.

Rugman, A. 2013. From the Richard N. Farmer to the Peter J. Buckley and Mark Casson AIB Dissertation Award. AlB Insights, 13(3): 4-6.

\section{Endnotes}

1 Fayerweather served as our first President (1960-1961) and also as Executive Secretary (1967-1970).

2 We would like to thank Susan Stern at the University of Miami for her valuable work in helping to retrieve abstracts.

3 The minutes stipulate that acceptable topics shall be defined according to the "book on international business research by Nehrt, Truitt and Wright (1970)."

4 José de la Torre, who had served in the Committee under Jeff Arpan, became the first Chair under this new system in 1987, and then rotated out the following year.

5 See, for example, Farmer and Richman (1965), Koontz (1969), and Negandhi and Estafan (1965).

6 At one time, JIBS published a list of completed IB dissertation titles on a regular basis, but we could find no record of when or why this practice ceased.

John D. Daniels, the Samuel N. Friedland Chair Professor Emeritus at the University of Miami, has served as AIB President and Dean of its Fellows. His dissertation from the University of Michigan won the annual AIB award. He has published articles in JIBS during four different decades and won one JIBS decade award. His co-authored IB text with Lee Radebaugh and Daniel Sullivan is in its 15th edition and has authorized translations in seven languages.

José de la Torre, Dean (Emeritus) at FIU's Chapman Graduate School of Business, previously at UCLA, INSEAD and Georgia State, and currently at Georgetown University, has published widely in IB strategy, served as director of companies in Mexico, India and Flori$\mathrm{da}$, and on business school Advisory Boards in France, Italy, Portugal, Argentina, Uruguay and Cyprus. A Fellow of the AIB, IAM, SMS and BALAS, he was named Outstanding Educator of the Year by the AOM in 2013. 